\title{
Ultra-light asymmetric photovoltaic sandwich structures
}

\author{
Julien Rion $^{\mathrm{a}}$, Yves Leterrier ${ }^{\mathrm{a}}$, Jan-Anders E. Månson ${ }^{\mathrm{a}, *}$, Jean-Marie Blairon ${ }^{\mathrm{b}}$ \\ a Laboratoire de Technologie des Composites et Polymères (LTC), Ecole Polytechnique Fédérale de Lausanne (EPFL), CH-1015 Lausanne, Switzerland \\ ${ }^{\mathrm{b}}$ Solvay Research and Technology, Rue de Ransbeek 310, Brussels B-1120, Belgium
}

\section{A R T I C L E I N F O}

\section{Article history:}

Received 10 June 2008

Received in revised form 10 March 2009

Accepted 3 May 2009

\section{Keywords:}

A. Honeycomb

A. Hybrid

B. Fracture

Silicon solar cells

\begin{abstract}
A B S T R A C T
This work evaluated the possibility of using silicon solar cells as load-carrying elements in composite sandwich structures. Such an ultra-light multifunctional structure is a new concept enabling weight, and thus energy, to be saved in high-tech applications such as solar cars, solar planes or satellites. Composite sandwich structures with a weight of $\sim 800 \mathrm{~g} / \mathrm{m}^{2}$ were developed, based on one $140 \mu \mathrm{m}$ thick skin made of $0 / 90^{\circ}$ carbon fiber-reinforced plastic (CFRP), one skin made of $130 \mu \mathrm{m}$ thick mono-crystalline silicon solar cells, thin stress transfer ribbons between the cells, and a $29 \mathrm{~kg} / \mathrm{m}^{3}$ honeycomb core. Particular attention was paid to investigating the strength of the solar cells under bending and tensile loads, and studying the influence of sandwich processing on their failure statistics. Two prototype multi-cell modules were produced to validate the concept. The asymmetric sandwich structure showed balanced mechanical strength; i.e. the solar cells, reinforcing ribbons, and 0/90 ${ }^{\circ} \mathrm{CFRP}$ skin were each of comparable strength, thus confirming the potential of this concept for producing stiff and ultra-lightweight solar panels.
\end{abstract}

(c) 2009 Elsevier Ltd. All rights reserved.

\section{Introduction}

Saving natural resources and energy is one of the key challenges of the 21 st century. In transportation, the most effective way to save energy is to diminish the moving mass, especially for aerial transportation. So, decreasing the weight of the structure of airplanes has become a main preoccupation for all aircraft constructors, from the biggest commercial airplanes [1,2] (to reduce running costs) to small private airplanes $[3,4]$. Therefore, composite sandwich structures are largely used in applications requiring high strength and stiffness-to-weight ratios, such as in the aeronautical domain [3-6]. For more unusual applications, such as ultra-light solar aircraft [7-9], competition solar cars, or satellite solar panels, the weight of the structures has to be pared to the absolute limit in order to save every gram. To this end, these ultra-light sandwich structures have been extensively studied by Rion et al. in order to understand the driving failure mechanisms and their relation with processing [10-12]. This type of structure was thus optimized, i.e. designed such that the failure loads of the various components were similar $[13,14]$.

In the above-mentioned applications, solar cells are often glued onto very light sandwich panels which provide sufficient stiffness [15-17]. In these designs, the solar cells add supplementary weight to the sandwich structure, with negligible mechanical contribution. To save more weight, the possible use of the mono-crystalline silicon (m-Si) solar cells to actually form the skin of the sandwich

\footnotetext{
* Corresponding author. Tel.: +41 216934281; fax: +41 216935880.

E-mail address: jan-anders.manson@epfl.ch (J.-A.E. Månson).
}

structure was investigated in the present work. The high elasticity modulus of m-Si (130-190 GPa depending on crystallographic direction) can provide very high stiffness to the sandwich structure. Furthermore, the thickness of such cells being in the range 130-300 $\mu \mathrm{m}$ makes these compatible with classic carbon fiberreinforced plastic (CFRP) skins. However, despite the high intrinsic strength of silicon (3-7 GPa depending on crystallographic direction $[18,19])$, its brittleness, and thus the low strength of the cells, limits the load-carrying capacity of this structure. Also, due to their finite size, a stress transfer device between the cells is required to ensure stress continuity on the photovoltaic (PV) skin.

Several studies have been conducted on asymmetric sandwich structures $[20,21]$ as also on multifunctional structures [22,23], but the present concept is completely new. This novel approach was thus carefully studied, following three main steps. Firstly, the strength of the solar cells was analyzed to identify design values for the asymmetric sandwich structure. Secondly, mechanical analysis of solar cells integrated into the sandwich structure was conducted to determine the influence of sandwich processing on cell strength, either due to damage or to residual stresses. Finally, curved multi-cell prototype modules were fabricated to demonstrate the feasibility of producing curve-shaped panels to fit, for example, wing profiles.

\section{Materials and methods}

The solar cells used were m-Si cells with $16.9 \%$ efficiency (S32, AzurSpace Solar Power $\mathrm{GmbH}$ ). The thickness of the cells was 
$130 \pm 10 \mu \mathrm{m}$ and their dimensions were $74 \mathrm{~mm} \times 31.9 \mathrm{~mm}$. The edges of the cells corresponded to the [ $\left[\begin{array}{lll}1 & 0 & 0\end{array}\right]$ and $\left[\begin{array}{lll}0 & 1 & 0\end{array}\right]$ crystal directions. The active face of the cells had an inverted pyramid surface texture in order to increase light absorption, especially for light rays with a low incidence angle [24-26]. As Münzer et al. [27] had observed a decrease in strength due to surface texture, the strength of the textured cells was compared to that of smooth $\mathrm{m}$-Si cells with no surface texture (RWE, 2PR/200-6540), 13.6\% efficiency, dimensions of $65 \times 40 \mathrm{~mm}^{2}$, and a thickness of $200 \pm 40 \mu \mathrm{m}$. Both types of cell had a $3-11 \mu \mathrm{m}$ thick silver layer on the back surface acting as a current collector.

The cells were first tested in 3-point bending with a $40 \mathrm{~mm}$ span between the loading points. As cracks propagate mainly under tension from surface and edge defects, the cells were tested with either the silicon active side or the silver-coated side under tension in order to investigate the quality of both front and rear surfaces. A total of 40 textured cells and 10 smooth cells were tested on each side.

When integrated as a skin in a sandwich structure, the solar cells are loaded mainly under tension and compression. As silicon cells are very brittle, the critical loading mode of the face is tensile loading, which causes crack opening and propagation in the cells. Compressive forces are less critical because the cracks do not tend to propagate. As a tensile load is more severe than a compressive load, the cells were tested under tension. The major problem with this test was to introduce the force in the cell without breaking it too early. This was solved by using steel plates with a beveled edge glued onto the cells, as depicted in Fig. 1. The load was introduced into the plate with pins, allowing rotation and self-alignment of the loaded cell, thus minimizing the edge effects on the cell. The loading rate was $0.2 \mathrm{~mm} / \mathrm{min}$. A total of 40 solar cells of the S32 type were tested.

Three different asymmetric sandwich structures were fabricated. Sandwich beams with a single cell on one face were fabricated to test the influence of sandwich processing on the mechanical properties of the cell. Sandwich beams with two cells on one face were produced to test the local reinforcement between cells. Two curved multi-cell modules, one with with four-cells and one with eight cells were eventually produced to demonstrate the feasibility of the asymmetric sandwich concept. As the goal of the study was to produce the lightest possible sandwich panels, carbon fibers, which have the highest strength- and stiffness-to-weight ratio amongst reinforcing fibers were chosen for the second face. The CFRP faces were made of stacks of a $70 \mu \mathrm{m}$ thick unidirectional (UD) carbon fiber pre-impregnated laminate (so-called prepreg, with a 35 wt\% EH84 epoxy matrix from Hexcel). The core was an $8 \mathrm{~mm}$ thick, $29 \mathrm{~kg} / \mathrm{m}^{3}$ Nomex honeycomb with a $3.2 \mathrm{~mm}$ cell size (Euro-Composite). Core-to-skin bonding was ensured by $50 \mathrm{~g} / \mathrm{m}^{2}$ epoxy adhesive film (VTA260, Advanced Composite Group).

The sandwich beams were $32 \mathrm{~mm}$ wide (width of one cell) by $460 \mathrm{~mm}$ long. Their detailed structure is depicted in Fig. 2. One skin was made of three layers of UD carbon prepreg $\left(0 / 90 / 0^{\circ}\right)$. This skin was voluntarily over-designed to ensure the failure of the solar cell side, hence enable studying the strength of the solar cell face. A detailed study of the CFRP face failure is reported in [12]. The other

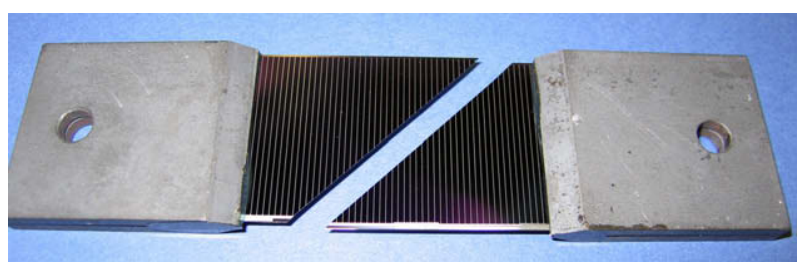

Fig. 1. Tensile test specimen for $\mathrm{S} 32 \mathrm{~m}-\mathrm{Si}$ solar cell with beveled steel plates. Failure of the cell along the [111] direction is evident.

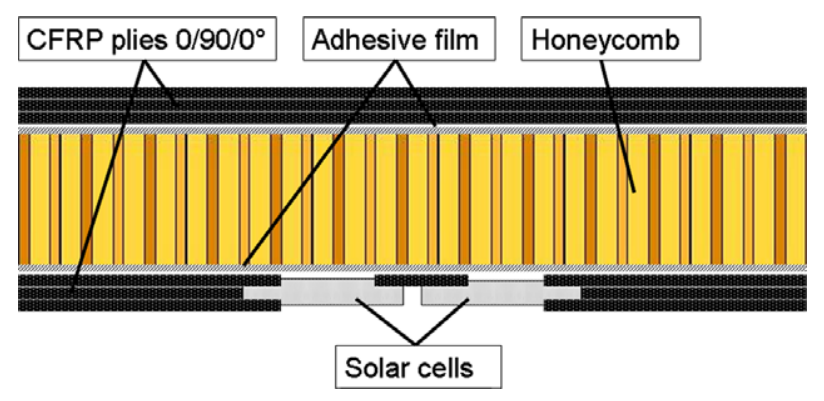

Fig. 2. Schematic lay-up of the sample with two solar cells as skin.

skin was composed of one or two solar cells in the middle of the beam, and three layers of prepregs $\left(0 / 90 / 0^{\circ}\right)$ on each side of the cells. The two $0^{\circ}$ plies overlapped the cell by $5 \mathrm{~mm}$ in order to ensure good stress transfer. No prepreg was present below the cells, which in fact formed the skin of the sandwich. To ensure stress transfer between the two adjacent cells, a $10 \mathrm{~mm}$ long ribbon of UD carbon prepreg was placed in the gap under the two cells. It should be noted that this CFRP ribbon cannot be used for electrically working panels, since the carbon fibers in contact with the cells would cause a short-circuit. Therefore, on the curved module with eight cells connected electrically, $100 \mathrm{~g} / \mathrm{m}^{2}$ glass fibers fabric was used as reinforcing ribbon.

When sandwich panels with a honeycomb core are manufactured in a single step using vacuum processing, the pressure in the core is not well-controlled because the honeycomb cells are closed by both skins, and air circulation is difficult [12]. The sandwich samples were thus produced in two steps in order to control the pressure in the honeycomb cells during the first step. The first cure was made with the solar cell and adjacent prepreg layers laid on the aluminum mold, with the honeycomb on top. The upper side of the honeycomb was open, so that the relative pressure in the honeycomb cell could be controlled. It was fixed either at -0.9 bar for 18 samples with one cell, or at -0.3 bar for 12 samples with one cell, in order to observe the effect of processing pressure on the strength of the structure and on the morphology of the adhesive menisci between skin and honeycomb cell walls. The three samples with two cells were cured at -0.9 bar. The second skin was cured in a second step, on the vacuum bag side, so that the solar cells on the mold side were not damaged. The same pressure was used in both steps. Cross-sections of the sandwich beams were embedded in an acrylic resin and polished in order to carry out microscopic observations under bright field illumination, as shown in Fig. 3. The resin fillets between honeycomb cell walls and skins formed properly on both the CFRP and silver face of

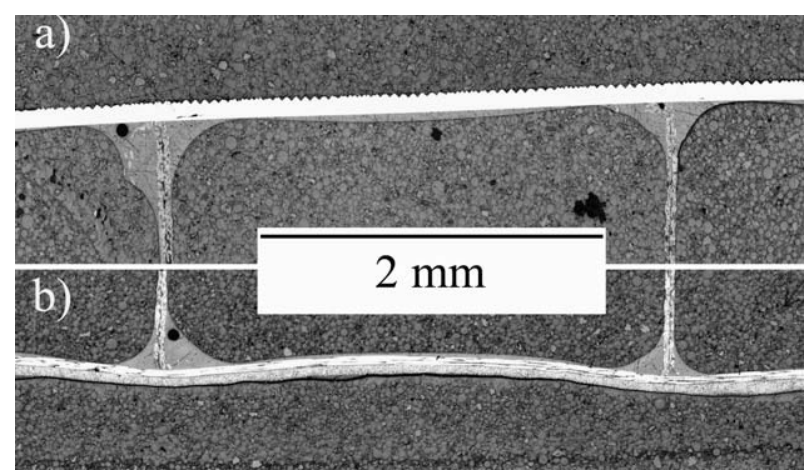

Fig. 3. Cross-section of the solar sandwich structure embedded in polishing resin, with the solar cell face up (a) and CFRP face down (b). Curing was carried out with -0.9 bar relative pressure in the vacuum bag. The inverted pyramid texture of the $\mathrm{Si}$ surface, two honeycomb cell walls, and resin menisci are visible. 


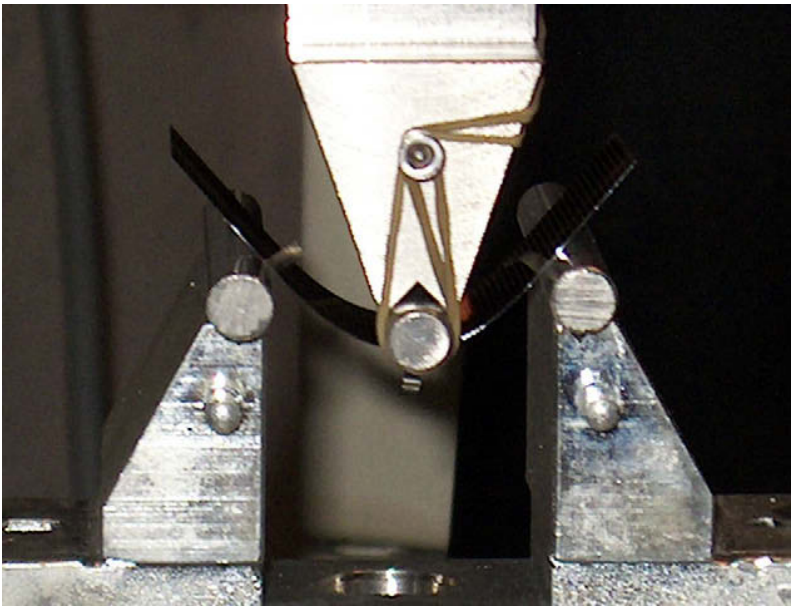

Fig. 4. 3-Point bending test on a $130 \mu \mathrm{m}$ thick m-Si solar cell.

the solar cells, thus ensuring a good core-to-skin bonding $[10,28]$. Taking into account the size of the fillets, an equivalent adhesive weight of approximately $30 \mathrm{~g} / \mathrm{m}^{2}$ was calculated with the model developed in [10]. It showed that nearly half of the adhesive film remained on the surface of the solar cell or CFRP skin, as can be observed in Fig. 3. This demonstrates the interest of using the adhesive deposition method on honeycomb [10] in order to lay the adhesive directly where the menisci form.

The beams were tested in 4-point bending with a $400 \mathrm{~mm}$ span between the outer supports and a $100 \mathrm{~mm}$ span between the loading points, and the solar cells centered on the set-up. Samples with a single solar cell were tested with the solar cell under tension. In order to test the reinforcing ribbon between the cells, one sample with two cells was tested with cells under tension, and the two others with the cells under compression.

\section{Mechanical analysis of solar cells}

\subsection{Bending and tensile strength of bare $\mathrm{m}$-Si cells}

Fig. 4 shows a bent single S32 cell under 3-point bending. Considerable deflection is evident, which was possible due to the small thickness/length ratio of the cell. This invalidated the use of simple linear beam theory in order to calculate the bending moment and thus the stress on the cells. The model developed by Schoenfelder et al. [29] was therefore used to take the large deflections into account.

In order to calculate the stresses, the thickness needs to be known accurately. In fact, the thickness of the cell includes the thickness of the silver backing, the texture height, and the thickness of the front silver grid, as sketched in Fig. 5. To find an adequate mean value for the cell thickness, the slope $\beta$ of the load-displacement curve during the 3-point bending test was measured in the linear part (i.e. at small displacements). As the thickness does not change during bending, the calculation of the thickness made at small displacements is valid at large deformation. Using linear beam theory, which is valid at small displacements, this slope was related to the thickness of an equivalent homogenous silicon rectangular section as follows:

$\frac{\delta}{P}=\frac{1}{\beta}=\frac{L_{3}}{4 E_{\mathrm{Si}} B t_{t h}^{3}}$

with $\delta$ the displacement of the loading point, $P$ the load, $L$ the span,

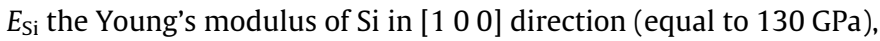
$B$ the width of the cell, and $t_{t h}$ the thickness of the equivalent homogenous silicon rectangular section, which writes as:

$t_{\text {th }}=3 \sqrt{\frac{\beta}{4 E_{\mathrm{Si}} B} L}$

The mean stress on the cell surface was calculated with this equivalent thickness. The slight influence of the silver backing on the rear side and the silver grid was disregarded, as explained in the following.

The total thickness of the textured cells as measured with a micrometer was found to be $133 \mu \mathrm{m}$, while the equivalent thickness, calculated to match the measured bending stiffness, was $16 \mu \mathrm{m}$ smaller, that is, between the total thickness and the thickness without the texture height. For smooth cells, the mean measured thickness was $240 \mu \mathrm{m}$, while the equivalent thickness calculated was $5 \mu \mathrm{m}$ smaller. A probabilistic approach based on the Weibull distribution was adopted in order to analyze the failure data of the brittle solar cells:

$P_{i}=\left(\frac{i-0.5}{n}\right)$

where $P_{i}$ is the failure probability of the $i$ th ranked specimen and $n$ is the total number of tested specimens. The Weibull parameters were calculated from the linear fit of the measured failure data as shown in Fig. 6 and summarized in Table 1. The corresponding failure probabilities are given by:

$P_{f}=1-e^{-\left(\frac{\sigma}{\sigma_{0}}\right)^{m}}$

where $m$ is the Weibull modulus and $\sigma_{0}$ the stress corresponding to $63 \%$ failure probability. The failure probabilities are represented in Fig. 7.

The mean strengths measured were approximately $10 \%$ of the intrinsic strength of $\mathrm{Si}\left(\begin{array}{lll}1 & 1 & 1\end{array}\right)$ [19], thus demonstrating the presence of defects causing stress concentrations. The textured solar cells failed at a slightly higher stress when the textured side was under compression rather than under tension. There was no dramatic reduction of strength due to stress concentrations caused by the texture. The slightly higher strength when the silver-coated
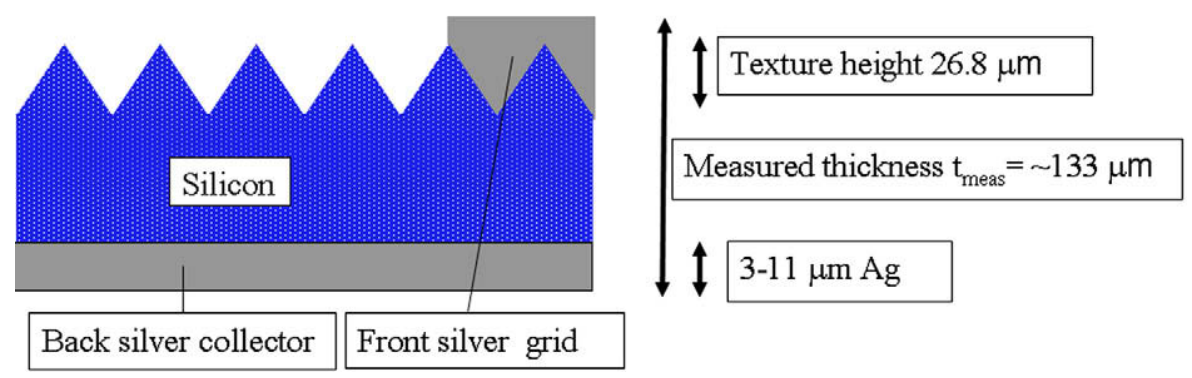

Fig. 5. Schematic cross-section of the textured m-Si solar cell. 

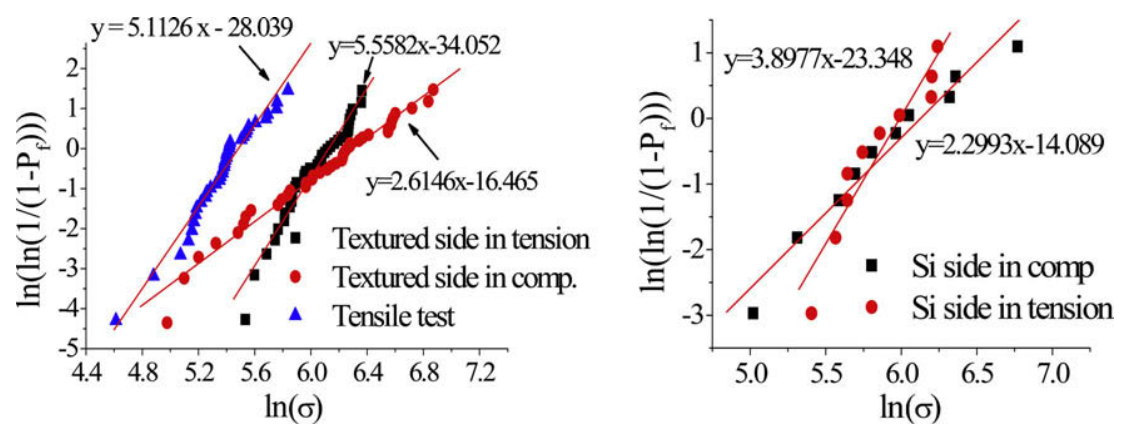

Fig. 6. Weibull analysis for textured cells under tension and bending (left), and smooth cells in bending (right).

Table 1

Weibull parameters and mean stress at failure calculated from the failure data of the textured and smooth cells in bending and of the textured cells under tensile load.

\begin{tabular}{llll}
\hline Bending: type of cell, side under tension & $\begin{array}{l}\text { Weibull modulus } \\
(\mathrm{m})\end{array}$ & $\begin{array}{l}\sigma_{0} \\
(\mathrm{MPa})\end{array}$ & $\begin{array}{l}\sigma_{\text {mean }} \\
(\mathrm{MPa})\end{array}$ \\
\hline Textured, Si active front side & 5.56 & 458 & 423 \\
Textured, silver-coated backing & 2.61 & 543 & 483 \\
Smooth, Si active front side & 3.90 & 399 & 361 \\
Smooth, silver-coated backing & 2.30 & 458 & 407 \\
Tension & & & \\
Bare cells & 5.11 & 240 & 221 \\
Integrated cells & 4.46 & 243 & 221 \\
\hline
\end{tabular}

backing was under tension was partly due to the fact that the silver layer also carried part of the tensile stresses. In fact, accounting for the presence of silver layer, and assuming that it deforms elastically $\left(E_{\mathrm{Ag}}=78 \mathrm{GPa}\right)$ reduces the calculated stress in the silicon on the silver side by $3 \%$ and $12 \%$ for $3 \mu \mathrm{m}$ and $11 \mu \mathrm{m}$ thick silver layer, respectively. In case the silver layer deformed plastically, the stress reduction in the silicon would be less pronounced. Stress in the silicon on the textured side was scarcely changed by taking the silver layer into account (less than $0.2 \%$ difference). But as the thickness of silver was not precisely known for each cell, the exact contribution could not be calculated. Another explanation for the very similar strength of both front and rear surfaces, despite different treatments, is that critical defects could be created on the edges of the cell during dicing [29]. The similar strength of textured and smooth sides is contrary to the measurements of Münzer et al. [27]. In fact, these authors measured the strength by pointloading [30] and did not take into account edge defects, which are not influenced by surface treatment. Moreover, they used different textures, which could create more severe stress concentrations. This issue will be further investigated using numerical simulations in a following section.

The Weibull modulus was higher, i.e. the scatter of strength values was smaller when the texture was under tension. This can be explained by the very regular etching of the textured face, removing most of the defects up to a given size. The size of the defects on the back-side was less controlled and more varied, causing higher scatter.

Even though the surface was not textured, similar behavior was measured on the smooth cells. The strength was slightly higher with the silver-coated backing under tension, but the scatter was also more pronounced. This may also be explained by a more careful etching of the front surface, thereby reducing scatter on this side, and also by the reinforcing effect of the silver layer on the back-side. The reduction of strength when the front face was under tension may also be partly due to the stresses caused by the silver grid deposition on the front side, as reported by Schneider et al. [31] who observed up to $30 \%$ strength reduction.
The strength of the smooth cells was lower than that of textured cells. The latter were thinner, and the present results demonstrate the positive influence of polishing and etching with further removal of defects and resulting increase of the strength in accordance with the results of Kray et al. [32]. This also confirms that the texturing process was not responsible for the low strength of the cells compared to the intrinsic strength of silicon, but that more critical defects were present in the solar cell.

Under tensile loading, all the cells broke at a $45^{\circ}$ angle to the loading direction, as observed on the broken sample in Fig. 1, which is the maximum shear direction and the weak (llll 111 ) plan of Si crystal. Their tensile strength was calculated from the failure load $F_{\max }$ measured during tensile testing as:

$\sigma=\frac{F_{\max }}{B t_{\text {tens }}}$

where $B$ is the width of the cell, and $t_{\text {tens }}$ is an equivalent thickness, equal to the cell thickness minus the height of the pyramids. The calculated strength provides a slightly overestimated mean value, which nevertheless is representative of the stress in the most loaded zones.

The Weibull failure distribution of the textured cells under tension is presented in Fig. 7, with a mean tensile strength equal to $221 \mathrm{MPa}$. This value is almost two times lower than that measured under bending, which could be due to several factors. Firstly, a slight misalignment of the tensile loading set-up can induce stress concentrations on one edge and reduce the load-carrying capacity. Secondly, the loaded volume was larger in the tensile test compared to the bending test, with resulting reduced mean strength for a given critical defect distribution. This is consistent with the Weibull modulus which was found to be equal to 5.11, that is, very close to the value measured under bending with the active Si side under tension. The $95 \%$ survival level, calculated with the Weibull

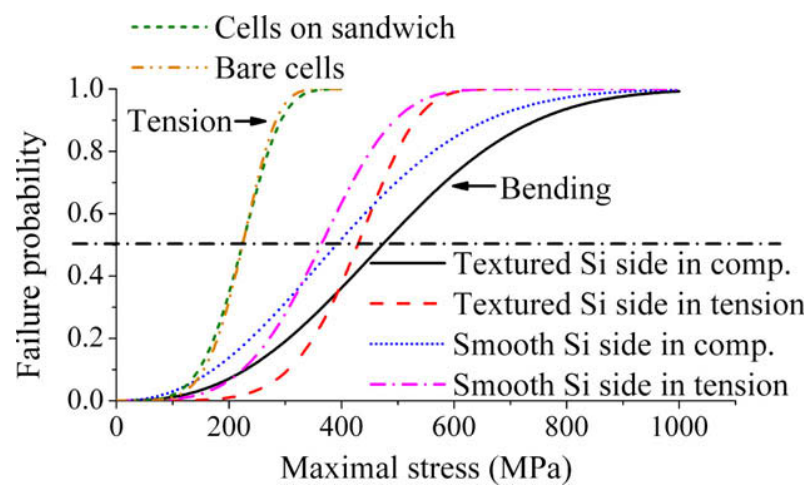

Fig. 7. Failure probability of smooth and textured solar cells under tension (textured cells only, bare or integrated into sandwich structures), or in bending with either front or back-side under tension. 
probability curve under tension, was $136 \mathrm{MPa}$. This value can be considered as a basic design value for the asymmetric sandwich structure.

\subsection{Tensile strength of $m$-Si cells integrated into sandwich structures}

All sandwich beams with one cell broke under bending due to tensile failure of the cell. The equivalent thickness used to calculate the stress in the cell was the same as for the tensile tests, i.e. the mean measured thickness minus the pyramid height. The mean stress and Weibull modulus calculated for the 18 samples cured with 0.9 bar pressure (as reported in Table 1 ) corresponded exactly to the values measured during tensile tests. The Weibull probability curves for both loading cases shown in Fig. 7 are in fact almost identical. This clearly indicated that sandwich processing did not damage the cells, and that residual stresses were not critical. This was further confirmed by the analysis of the 12 samples produced with reduced process pressure of 0.3 bar, with a strength equal to $211 \pm 59 \mathrm{MPa}$.

The mean load per unit width in the cell at failure for the samples cured with 0.9 bar pressure was $N_{\text {cell }}=23 \pm 6 \mathrm{~N} / \mathrm{mm}$. This value is close to the line load causing compressive failure of a $0 / 90^{\circ}$ CFRP skin due to local instability, equal to $28 \mathrm{~N} / \mathrm{mm}$ [12]. However, the $95 \%$ survival stress level of $136 \mathrm{MPa}$ calculated in the previous section corresponds to a line load of $14.3 \mathrm{~N} / \mathrm{mm}$, which represents a design limit for ultra-light asymmetric PV modules. The complete design of a large-size panel should also take into account the probabilistic failure load distribution of the cells, in order to minimize the risk of complete failure of the panel.

When the beams with two cells were tested with the cells under tension, failure was due to tensile failure of the cells, showing that the very thin stress transfer ribbon was strong enough for tensile loading. When the solar cell face was under compression, the beams failed due to compressive failure of the ribbon at a mean stress of $396 \mathrm{MPa}$ corresponding to a line load of $27.7 \mathrm{~N} / \mathrm{mm}$. This value is larger than the maximum line load supported under ten- sion by the cell, and this is therefore sufficient to build panels with symmetrical strength. The present carbon fiber-reinforced ribbons should be replaced by glass fiber-reinforced ribbons of comparable mechanical properties to avoid electrical short-circuits in operating PV modules.

\subsection{Numerical analysis of stress concentrations in textured solar cells}

In order to further investigate the experimental failure data of the cells a numerical analysis of stress concentrations in the textured cells was carried out. Fig. 8 shows the inverted pyramid surface texture of the $\mathrm{m}$-Si cells produced by photolithography and selective etching [33] of the silicon and resulting stress concentration at sharp corners. The corresponding reduction of tensile strength of the textured surface is a well-known phenomenon already studied in [27]. Since the magnitude of this effect depends on the texture geometry, scanning electron microscope imaging was used for accurate measurement of the texture (Fig. 8a) and radius of curvature of the sharp corner from a section of a broken cell (Fig. 8b). The average curvature radius of the pyramid tips over 10 measurements was found to be equal to $357 \mathrm{~nm}$. This value was used for the fillet radius of all the sharp edges in a finite element model (FEM, Abaqus ${ }^{\circledR}$ ) of the textured surface. To investigate the influence of fillet radius, simulations were also conducted with double and half size radii. A computer assisted design model of the highly regular texture was constructed (Fig. 8c). For the numerical analysis of stress concentrations resulting from the texture, the silicon cell was represented by a single texture unit. In the FEM simulation, the problem had to be solved at two different scales (100 $\mu \mathrm{m}$ thick cells and several $100 \mathrm{~nm}$ curvature radius of the texture). A sub-modeling technique was therefore used. A first model was built with element sizes adapted to the global cell scale. This was used to calculate the displacement field near the region of interest, i.e. the sharp edges in texturation, when the cell was under tensile loading or cylindrical bending. A second model, representing only the region of interest, was then constructed, with
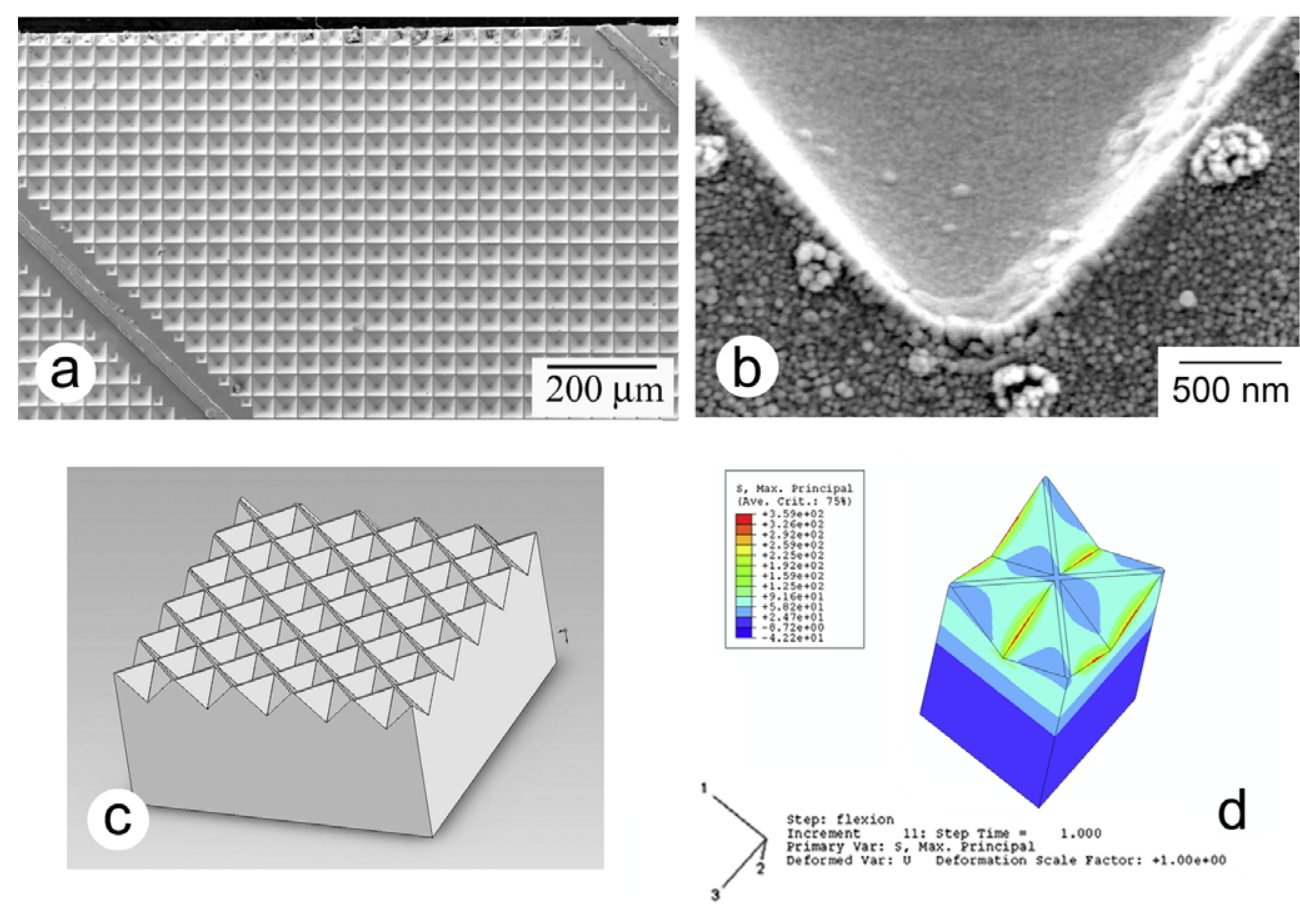

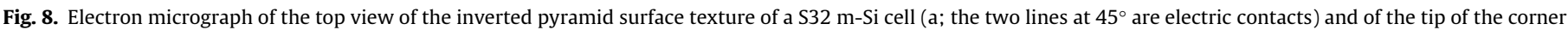

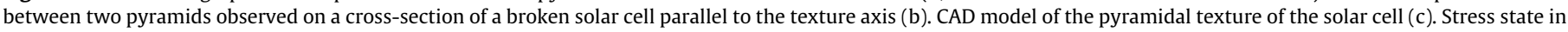
a single texture unit in a cell bend to a radius of curvature of $10 \mathrm{~cm}$ (d). 
Table 2

Stress concentration factor $\lambda$ due to the texture of the surface with different fillet radii in the texture.

\begin{tabular}{lllll}
\hline Fillet radius & Infinite (no texture) & $714 \mathrm{~nm}$ & $357 \mathrm{~nm}$ & $179 \mathrm{~nm}$ \\
\hline$\lambda$ tensile loading & 1 & 6.4 & 7.8 & 12.4 \\
$\lambda$ bending & 1 & 5.6 & 6.8 & 10.7
\end{tabular}

very fine elements allowing accurate stress calculation at the sharp edges. The displacement obtained as a result of the first global model was applied in this second model. For the silicon material, an orthotropic material with diamond symmetry was used with the following elastic constants: $C_{11}=166 \mathrm{GPa}, C_{12}=64 \mathrm{GPa}$ and $C_{44}=79.6 \mathrm{GPa}$. Maximal stresses were identified in the stress concentration area at the sharp edges of the texture (Fig. 8d), and the stress concentration factor is given in Table 2 by the ratio $\lambda$ between the maximal stress and the mean stress without texture.

The stress concentration factors were similar in bending and tensile loading. They increased rapidly when the radius became smaller. Considering a fillet radius of $357 \mathrm{~nm}$ and an intrinsic strength of $4 \mathrm{GPa}$ for silicon, the cell would break at a mean stress of $513 \mathrm{MPa}$ under tension and $588 \mathrm{MPa}$ under bending due to the stress concentration effects. As the mean measured tensile and bending stresses were smaller (221 MPa and $423 \mathrm{MPa}$, respectively), the present analysis implies that other, more critical, defects were present in the cells, causing early failure. This confirms the results of the bending tests, showing little difference between the strength of the textured and flat faces.

\section{Multi-cell modules}

In order to prove the feasibility of manufacturing curved asymmetric sandwiches with solar cells as a skin, two prototype modules with four and eight cells were produced, as shown in Fig. 9. The cells were fixed together with adhesive tape on the $\mathrm{Si}$ side and with a $1 \mathrm{~mm}$ gap in-between and placed in an $\mathrm{Al}$ mold with a simple curvature of $2 \mathrm{~m}^{-1}$. Small pieces of adhesive tape were placed at the cells corners in the case of the four-cell module, which resulted in local damage of the cells during processing. For this reason, continuous strips of the adhesive tape were used to maintain the cells in place in the eight-cells module, and this avoided cell damage. The adhesive tape would be unnecessary in case the cells would be glued on an encapsulation film and connected electrically to each other. Reinforcing $10 \mathrm{~mm}$-wide CFRP ribbons for the four-cells module, and glass fibers ribbons for the eight-cells module were placed over the gaps around the cells on the $\mathrm{Ag}$ side, and a $0 / 90^{\circ}$ prepreg layer was adjusted around the cells with a $5 \mathrm{~mm}$ overlap on the edges of the cells. As in the case of sandwich beams, no prepreg was present below the cells, which again formed the skin of the sandwich. Adhesive film $\left(50 \mathrm{~g} / \mathrm{m}^{2}\right)$ was laid over the cells, and the honeycomb core was then placed on top, and closed using the $0 / 90^{\circ}$ prepreg skin with $50 \mathrm{~g} / \mathrm{m}^{2}$ adhesive. The assembly was cured under a vacuum bag with -0.7 bar relative pressure. The sandwich constituents including the cells bent following the curvature of the mold when vacuum was applied and the produced modules were curved after curing and demolding.

The cells in the two modules did not break during manufacturing due the curvature, but as mentioned above cells in the fourcells module broke locally where the adhesive tapes were placed. This underlined the need to have a very regular molding surface, which should be achieved with an encapsulation film to protect the cells against environmental attacks $[34,35]$. This was not included in the present work. The photovoltaic performance of the eight-cells module was not measured but it was verified that the

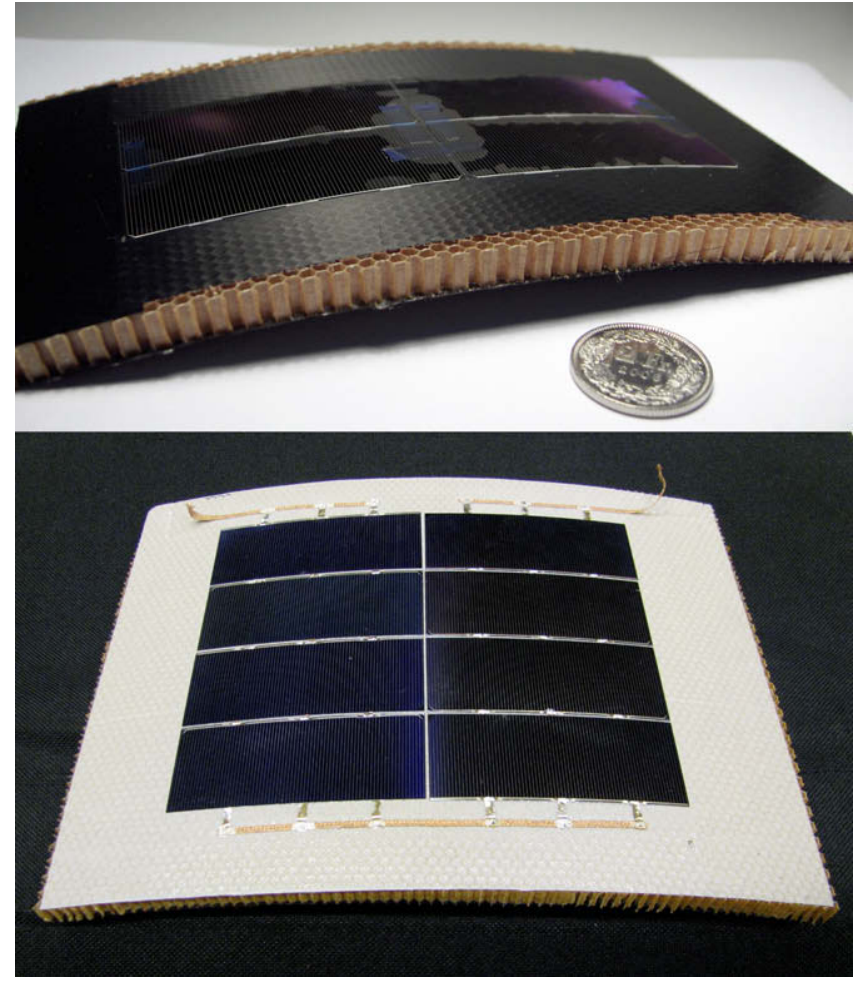

Fig. 9. Curved prototype sandwich modules with 4 (top) and 8 (bottom) integrated m-Si S32 solar cells as a skin.

electrical continuity of the cells was not compromised by the manufacture process. The prototype panel confirmed the possibility of producing stiff curved-shape PV modules with a weight of $\sim 800 \mathrm{~g} / \mathrm{m}^{2}$, and this opens the way for multiple uses of this new type of structure. A symmetric sandwich structure with solar cells glued on one face, with stiffness and strength properties similar to the multi-cell modules will weight about $200 \mathrm{~g} / \mathrm{m}^{2}$ more. The present asymmetric design enables a $20 \%$ weight reduction for ultra-light sandwich panels and is thus very interesting for light and stiff structures submitted to small loads.

\section{Conclusions}

The concept of an asymmetric photovoltaic sandwich structure comprising one skin made of solar cells was evaluated. The strength of mono-crystalline Si solar cells in 3-point bending was found to be equal to $420 \mathrm{MPa}$, which is approximately $10 \%$ of the intrinsic strength of Si( $\left.\begin{array}{lll}1 & 1 & 1\end{array}\right)$. Cell strength was similar when measured in bending with the textured side under tension or compression, as well as with the smooth cells without texture. This result, combined with a FEM simulation of stress concentration factors showed that the inverted pyramids texture of the solar cells was not responsible for their early failure and that more severe defects caused the failure of the cell. The mean tensile strength of the cell was found to be $221 \mathrm{MPa}$. The strength of the cells was unchanged when integrated into the sandwich structure, thus confirming the process compatibility of the cells, and the low residual stresses.

Two prototype multi-cell modules were manufactured including four and eight cells and thin stress transfer ribbons. The ribbons were strong enough to enable large-size flat or curved panels to be built. The asymmetric sandwich structure showed balanced strength properties, the strength of the solar cells, reinforcing ribbon, and $0 /$ $90^{\circ}$ CFRP skin being similar, thus underlining the potential of this concept for producing stiff and ultra-lightweight solar panels. The interesting mechanical properties identified in bending with corre- 
sponding $20 \%$ weight savings compared to traditional symmetric designs have to be confirmed once final application and loading cases are defined and the structure optimized to this end. Furthermore, a scale-up of the process and real size panel testing has to be made to confirm the suitability of the asymmetric concept for defined loading case. A detailed reliability analysis has moreover to be conducted by taking into account the strength scatter of the cells in order to build panels with satisfying security factors.

\section{Acknowledgements}

The authors wish to acknowledge the EPFL and Swiss Innovation Promotion Agency (CTI, \#8002.1, DCPP-NM) for financial support.

\section{References}

[1] Beral B. Airbus structure and technology - next steps and vision. In: Proceedings of 16 th international conference on composite materials. Kyoto: 2007.

[2] Roesler WG, Sarh B, Kismarton MU. Composite structures: the first 100 years. In: Proceedings of 16th international conference on composite materials. Kyoto; 2007.

[3] Funke H. Systematische entwicklung von ultra-leichtbaukonstruktionen in faserverbund-wabensandwichbauweise am beispiel eines kleinflugzeuges. PhD Thesis. Universität-GH Paderborn; 2001

[4] Funke H. Development of the ultralight aircraft silence. JEC - Compos 2004;10:52-4.

[5] Middleton DH. Composite materials in aircraft structures. Harlow: Longman; 1990.

[6] Rozant O, Bourban PE, Månson J-AE. Manufacturing of three dimensional sandwich parts by direct thermoforming. Compos Part A: Appl Sci Manufact 2001;32(11):1593-601.

[7] Baldock N, Mokhtarzadeh-Dehghan MR. A study of solar-powered, highaltitude unmanned aerial vehicles. Aircraft Eng Aerosp Technol 2006;78(3):187-93.

[8] Cestino E. Design of solar high altitude long endurance aircraft for multi payload and operations. Aerosp Sci Technol 2006;10(6):541-50.

[9] Romeo G, Frulla G, Cestino E, Heliplat Corsino G. Design, aerodynamic, structural analysis of long-endurance solar-powered stratospheric platform. J Aircraft 2004;41(6):1505-20.

[10] Rion J, Demarco F, Leterrier Y, Månson J-AE. Damage analysis of ultralight sandwich structures. In: Proceedings of 16 th international conference on composite materials. Kyoto; 2007.

[11] Rion J, Geiser A, Leterrier Y, Månson J-AE. Ultralight composite sandwich structure: optimization of skin to honeycomb core bonding. In: Proceedings of 27th international conference of SAMPE Europe. Paris; 2006.

[12] Rion J, Stutz S, Leterrier Y, Månson J-AE. Influence of process pressure on local facesheet instability for ultralight sandwich structures. In: Proceedings of 8 th international conference on sandwich structures, Porto. J Sandwich Struct Mater; in press.

[13] Triantafillou TC, Gibson LJ. Minimum weight design of foam core sandwich panels for a given strength. Mater Sci Eng 1987;95:55-62.

[14] Triantafillou TC, Gibson LJ. Failure mode maps for foam core sandwich beams. Mater Sci Eng 1987;95:37-53.

[15] Japanese patent 2002353489 a: Sandwich panel for mounting solar cell, 06.12.2002.

[16] German patent 19715788 c1: Solargenerator für satelliten, 08.10.1998.

[17] United states patent 4.394.529: Solar cell array with lightweight support structure, 19.07.1983.

[18] Petersen KE. Silicon as a mechanical material. Proc IEEE 1982;70:420-57.

[19] Kozhushko VV, Hess P. Anisotropy of Si studied by a laser based contact free method. Phys Rev B 2007;76(14):144105-11.

[20] Castanie B, Barrau JJ, Jaouen JP. Theoretical and experimental analysis of asymmetric sandwich structures. Compos Struct 2002;55(3):295-306.

[21] Kim J, Swanson SR. Effect of unequal face thickness on load resistance of sandwich beams. J Sandwich Struct Mater 2004;6(2):145-66.

[22] Jeon JH, Hwang W, Park HC, Park WS. Buckling characteristics of smart skin structures. Compos Struct 2004;63(3-4):427-37.

[23] You CS, Hwang W, Park HC, Lee RM, Park WS. Microstrip antenna for sar application with composite sandwich construction: surface-antennastructure demonstration. J Compos Mater 2003;37(4):351-64.

[24] Nussbaumer H, Willeke G, Bucher E. Optical behavior of textured silicon. J Appl Phys 1994;75(4):2202-9.

[25] Smith AW, Rohatgi A. A new texturing geometry for producing high-efficiency solar-cells with no antireflection coatings. Sol Energy Mater Sol Cells 1993;29(1):51-65.

[26] Zhao JH, Wang AH, Green MA, Ferrazza F. 19.8\% Efficient "Honeycomb" textured multicrystalline and $24.4 \%$ monocrystalline silicon solar cells. Appl Phys Lett 1998;73(14):1991-3.

[27] Munzer KA, Holdermann KT, Schlosser RE, Sterk S. Thin monocrystalline silicon solar cells. IEEE Trans Electron Dev 1999;46(10):2055-61.

[28] Okada R, Kortschot MT. The role of the resin fillet in the delamination of honeycomb sandwich structures. Compos Sci Technol 2002;62(14):1811-9.

[29] Schoenfelder S, Ebert M, Landesberger C, Bock K, Bagdahn J. Investigations of the influence of dicing techniques on the strength properties of thin silicon. Microelectron Reliab 2007;47(2-3):168-78.

[30] Behnken H, Apel M, Franke D. Simulation of mechanical stress during bending tests for crystalline wafers. In: Proceedings of 3rd world conference on photovoltaic energy conversion. Osaka, Japan; 2003.

[31] Schneider A, Bühler G, Huster F, Peter K, Fath P. Impact of individual process steps on the stability of silicon solar cells studied with a simple mechanical stability tester. In: Proceedings of conference on PV in Europe from PV technology to energy solutions. Rome; 2002.

[32] Kray D, Kampwerth H, Schneiderlöchner E, Grohe A, Glunz SW. Comprehensive experimental study on the performance of very thin laser-fired high-efficiency solar cells. In: Proceedings of 19th European photovoltaic solar energy conference. Paris; 2004

[33] Juvonen T, Harkonen J, Kuivalainen R. High efficiency single crystalline silicon solar cells. Phys Scripta 2002;T101:96-8.

[34] Nowlan MJ, Maglitta JC, Darkazalli G, Lamp T. Ultralight photovoltaic modules for unmanned aerial vehicles. In: Proceedings of 26th PVSC. Anaheim; 1997.

[35] Snowdon D, Green J, Cousins P, Stone S. Composite curved laminates for the UNSW sunswift II solar array. In: Proceedings of solar world congress; 2001. 